\title{
Penerapan Sistem Pendukung Keputusan Dengan Metode Naïve Bayes Dalam Menentukan Kualitas Bibit Padi Unggul Pada Balai Pertanian Pasar Miring
}

\author{
Muhammad Zulfikar ${ }^{1 *}$, Hasanul Fahmi \\ ${ }^{1,2}$ STMIK Pelita Nusantara \\ Jl. Iskandar Muda No. 1 Medan Kode Pos 20154 \\ Corresponding : zulfikarmhd5@gmail.com
}

\begin{abstract}
Abstrak - Belum adanya pemilihan bibit padi berkualitas tinggiini menyebabkan pertanian saat ini pada Balai Pertanian Pasar Miring menjadi merosot kualitasnya. Untuk itu diperlukan perancangan sistem pakar dimulai dengan menganalisis tujuan dan rancangan aplikasi sistem dibangun untuk memahami kebutuhan pengguna sistem. Ruang lingkup permasalahan dalam proses pembudidayaan jenis bibit padi unggul dengan metode Naive Bayes yaitu penentuan kualitas jenis padi unggul dalam pembudidayaan ini menggunakan tujuh jenis bibit padi yaitu Mira, Ciherang, Mikongga, Cibogo, Sertani, Mapan, dan Inpari 43 Gsr. Dalam penentuan kualitas jenis bibit padi unggul berdasarkan dari 4 kriteria yaitu : kultur cuaca, produksi, serangan hama dan hasil panen. Data penelitian terdiri dari Data Bibit (Ciherang, Mikongga, Cibogo, Mapan P-05, Sertani 13, Mira, Inpari 43 GSR), Data Kriteria terdiri dari Kultur Cuaca Produksi (C2), Serangan Hama (C3), Hasil Panen (C4) dan 13 data training. Hasil perangkingan yaitu Kode, R2 Nama Bibit, Ciherang memperoleh Nilai Probabilitas 0.3334534 dengan keterangan Kualitas Baik, Kode R3 Nama Bibit, Mikongga Nilai Probabilitas 0.3334534.

Kata kunci: Tanaman Bibit Unggul, SPK, Perangkingan, Naive Bayes
\end{abstract}

\section{Pendahuluan}

Secara umum hasil padi yang berasal dari benih jenis Mapan 05, menghasilkan rasa nasi yang pulen dengan disertai wangi yang cukup baik. Bahkan beras yang dihasilkan bisa masuk pada kualitas premium. Ketahui juga oleh anda mengenai Tanaman Cabai Tiba-Tiba Layu untuk langkah pencegahan Selain itu juga dengan menggunakan benih dari mapan 05 usia dari padi relatif pendek bila dibandingkan dengan jenis padi lain yakni bekisar 113 sampai dengan 115 hari setelah melalui masa semai. Apabila setelah masa tanam maka hanya memerlukan waktu sekitar 85 sampai dengan 90 hari saja. Adapun kelemahan dari benih jenis Mapan 05, terletak pada rendemen berasnya, Hal ini dirasa cukup rendah apabila dibandingkankan dengan jenis padi yang lain. Rendahnya produktivitas padi sawah antara lain disebabkan oleh terbatasnya penerapan bibit padi unggul. Penggunaan bibit atau bibit unggul diakui telah menjadi satu faktor kunci keberhasilan dalam peningkatan produksi. Bibit unggul yang diperoleh dari varietas hasil pemuliaan tanaman disebut dengan bibit penjenis. Pemerintah telah menetapkan ketentuan pokok maupun pengawasan untuk menghasilkan bibit yang bersertifikat atau bibit sebar yang terjamin mutu, baik genetik dan kemurniannya [1].

Sistem Pendukung Keputusan (SPK) merupakan sistem informasi interaktif yang menyediakan informasi, pemodelan, dan pemanipulasi data [2]. Sistem itu digunakan untuk membantu pengambilan keputusan dalam suatu yang semistruktur dan situasi tidak terstruktur, tak seorangpun tahu secara pasti bagaimanakeputusan seharusnya dibuat. Sehingga SPK dapat diterapkan dalam proses memberikan solusi dalam mengambil keputusan terhadap suatu permasalahan dalam kondisi banyak kriteria atau Multicriteria Decicion Making (MCDM). Dalam SPK, solusi yang diberikan ditampilkan adalah saran dalam bentuk peringkat [3]. SPK dapat bekerja secara maksimal dengan menggunakan metode Naive Bayes. Metode Naive Bayes merupakan salah satu metode pengambilan keputusan untuk menyelesaikan masalah dengan menentukan nilai peluang dari kejadian dan nilai evidence (bukti) yang didapat dari fakta tentang objek yang diteliti [4].

Penelitian berjudul, Penerapan Metode Naive Bayes Dalam Pemilihan Kualitas Jenis Rumput Taman CV. Rumput Kita Landscape, menjelaskan para pengelola jasa taman dalam menentukan kualitas rumput menunjukkan belum adanya pemanfaatan sistem komputer dalam pemilihan jenis rumput taman yang berkualitas, menyebabkan terjadi kesalahan dalam menentukan kualitas rumput terbaik [5].

Dalam permasalahan ini metode Naïve Bayes digunakan sebagai Sistem Pengambil Keputusan (SPK). Naïve bayes merupakan metode pengklasifikasian ada tidaknya ciri tertentu dari sebuah kelas [6]. Empat kriteria pemilihan kualitas jenis rumput taman yaitu suhu udara, curah hujan, kelembapan udara dan harga pasar. Pengambilan 
keputusan dengan metode ini membutuhkan informasi probabilitas setiap alternatif pada persoalan yang dihadapi untuk menghasilkan nilai harapan sebagai dasar pengambilan keputusan. Permasalahan pemilihan kualitas budidaya dalam penentuan bibit padi unggul pada Balai Pertanian Pasar Miring yaitu seringnya terjadinya kesalahan dalam menentukan kualitas padi terbaik. Belum adanya pemilihan bibit padi unggul ini menyebabkan pertanian saat ini pada Balai Pertanian Pasar Miring menjadi merosot kualitasnya, Dengan memperhitungkan segala kriteria pengambilan keputusan dalam menentukan bibit padi unggul dengan kualitas yang terbaik, tujuan penelitian dilakukan adalah membantu pihak manajemen dalam menentukan kualitas jenis bibit padi unggul pada Balai Pertanian Pasar Miring. Mengurangi tingkat kesalahan dalam penentuan jenis bibit padi unggul pada Balai Pertanian Pasar Miring.

\section{Tinjauan Pustaka}

\subsection{Sistem Pengambil Keputusan}

Tiga tujuan yang harus dicapai oleh pendukung keputusan, yaitu 1) Sistem harus dapat membantu manager dalam mengambil keputusan guna memecahkan masalah semi struktur 2) Sistem harus dapat membantu manajer, bukan menggantikannya 3) Sistem harus dapat mengingkatkan efetivitas pengambilan keputusan manajer [7]. Komponenkomponen Sistem Pendukung Keputusan terdiri dari [8] :

\section{Tabel 1. Keterangan Formula Bayes}

\begin{tabular}{|c|c|}
\hline Parameter & Keterangan \\
\hline $\mathrm{P}(\mathrm{H} \mid \mathrm{E})$ & $\begin{array}{l}\text { Probabilitas akhir bersyarat (conditional probability) suatu hipotesa } \mathrm{H} \text { terjadi jika diberikan } \\
\text { bukti (evidence) E terjadi. }\end{array}$ \\
\hline $\mathrm{P}(\mathrm{E} \mid \mathrm{H})$ & Probabilitas sebuah bukti E terjadi akan mempengaruhi hipotesa $\mathrm{H}$. \\
\hline $\mathrm{P}(\mathrm{H})$ & Probabilitas awal (priori) hipotesa $\mathrm{H}$ terjadi tanpa memandang bukti apapun \\
\hline $\mathrm{P}(\mathrm{E})$ & Probabilitas awal (priori) bukti E terjadi tanpa memandang hipotesa/bukti yang lainnya \\
\hline
\end{tabular}

Ide dasar dari aturan Bayes adalah bahwa hasil dari hipotesa atau peristiwa $(\mathrm{H})$ dapat diperkirakan berdasarkan pada beberapa bukti (E) yang diamati. Adalah beberapa hal penting dari aturan Bayes 1) Sebuah probabilitas awal/priori $\mathrm{H}$ atau $\mathrm{P}(\mathrm{H})$ adalah probabilitas dari suatu hipotesa sebelum bukti diamati 2) Sebuah probabilitas akhir $\mathrm{H}$ atau $\mathrm{P}(\mathrm{H} \mid \mathrm{E})$ adalah probabilitas dari suatu hipotesa setelah bukti diamati [11].

\subsection{Data Training}

Data training yaitu objek data yang memiliki label kelas yang diketahui. Proses data klasifikasi a. Data Management. termasuk database, yang mengandung data yang relevan untuk berbagai situasi dan diatur oleh software yang disebut Database Management Systems (DBMS).

b. Model Management. Melibatkan model finansial, statistical, management science, atau berbagai model kuantitatif lainnya, sehingga dapat memberikan ke sistem suatu kemampuan analitis, dan manajemen software yang diperlukan.

c. Communication (dialog subsystem). User dapat berkomunikasi dan memberikan perintah pada DSS melalui subsistem.

d. Kwonledge Management. Subsistem mendukung subsistem lain atau bertindak sebagai komponen yang berdiri sendiri.

\subsection{Naive Bayes}

Algoritma Teorema Bayes dan mengasumsikan semua atribut independen atau tidak saling ketergantungan yang diberikan oleh nilai pada variabel kelas [9]. Naive Bayes didefenisikan sebagai pengklasifikasian dengan metode probabilitas dan statistik memprediksi peluang dimasa depan berdasarkan pengalaman dimasa sebelumnya. Dalam Bayes (terutama Naive Bayes), maksud independensi yang kuat pada fitur adalah bahwa sebuah fitur pada sebuah data tidak berkaitan dengan ada atau tidaknya fitur lain dalam data yang sama.

Prediksi Bayes didasarkan pada teorema Bayes dengan formula [10]: $P(H \mid E)=\frac{P(E \mid H) \times P(H)}{P(E)}$

memiliki dua tahap, yang pertama adalah Learning: dimana training data dianalisa dengan menggunakan sebuah algoritma klasifikasi. Classification, pada tahap ini test data digunakan untuk mengestimasi ketepatan dari classification rules. Teori keputusan Bayes adalah pendekatan statistik yang fundamental dalam data. Pendekatan ini didasarkan pada kuantitatif trade-off antara berbagai keputusan klasifikasi dengan menggunakan probabilitas [12].

1. Data Konsisten dan Tidak Konsisten 
Tabel 2. Data Konsisten dan Tidak Konsisten

\begin{tabular}{|c|c|c|c|c|}
\hline \multicolumn{4}{|c|}{ Atribut } & Label \\
\hline Day & Cuaca & Tempratur & Kecepatan Angin & Berolahraga \\
\hline 1 & Cerah & Normal & Pelan & Ya \\
\hline 2 & Cerah & Normal & Pelan & $\mathrm{Ya}$ \\
\hline 3 & Cerah & Normal & Kencang & $\mathrm{Ya}$ \\
\hline 5 & Cerah & Tinggi & Pelan & $\mathrm{Ya}$ \\
\hline 6 & Hujan & Normal & Kencang & $\mathrm{Ya}$ \\
\hline 7 & Cerah & Normal & Pelan & Ya \\
\hline 8 & Cerah & Normal & Pelan & $\mathrm{Ya}$ \\
\hline 9 & Cerah & Normal & Pelan & Tidak \\
\hline
\end{tabular}

2. Data Konsisten, suatu data disebut konsisten, jika setiap atributnya memiliki nilai target yang sama.

Tabel 2.1 Data Konsisten

\begin{tabular}{|c|c|c|c|c|}
\hline \multicolumn{3}{|c|}{ Atribut } & Label \\
\hline Day & Cuaca & Tempratur & Kecepatan Angin & Berolahraga \\
\hline 1 & Cerah & Normal & Pelan & Ya \\
\hline 2 & Cerah & Normal & Pelan & Ya \\
\hline 3 & Cerah & Normal & Kencang & Ya \\
\hline
\end{tabular}

3. Data Tidak Konsisten, suatu data disebuat tidak konsisten, jika setiap atributn memiliki nilai

target yang sama, tetapi nilai yang berbeda untuk atribut.

Tabel 3. Data Tidak Konsisten

\begin{tabular}{|c|c|c|c|c|}
\hline \multicolumn{3}{|c|}{ Atribut } & Label \\
\hline Day & Cuaca & Tempratur & Kecepatan Angin & Berolahraga \\
\hline 1 & Cerah & Normal & Pelan & Ya \\
\hline 2 & Cerah & Tinggi & Pelan & Ya \\
\hline 3 & Hujan & Normal & Kencang & Ya \\
\hline
\end{tabular}

4. Data Biasa, suatu data disebut data biasa jika memiliki target atau keputusan yang berbeda sedangkan intsance pada semua atributnya sama.

Tabel 4. Data Biasa

\begin{tabular}{|c|c|c|c|c|}
\hline \multicolumn{3}{|c|}{ Atribut } & Label \\
\hline Day & Cuaca & Tempratur & Kecepatan Angin & Berolahraga \\
\hline 1 & Cerah & Normal & Pelan & Ya \\
\hline 2 & Cerah & Normal & Pelan & Ya \\
\hline 3 & Cerah & Normal & Pelan & Tidak \\
\hline
\end{tabular}

\section{Metode Penelitian}

Data yang diperoleh melalui wawancara dengan pihak Balai Pertanian Pasar Miring. Tahapan penelitian :

1. Pengumpulan data

Proses memperoleh keterangan dengan cara tanya jawab sambil bertatap muka antara pewawancara dengan pihak balai pertanian pasar miring yang berwenang memberikan data yang berkaitan dengan masalah yang diteliti. Wawancara menggunakan daftar pertanyaan yang berkaitan dengan tujuan penelitian. Daftar diberikan kepada responden (pimpinan dan staf perusahaan) dengan harapan mereka akan memberikan tanggapan terhadap daftar pertanyaan. Pengumpulan data yang berasal dari buku, jurnal, laporan serta sumber informasi tertulis lainnya yang terkait dengan masalah yang diteliti.

2. Analisa Sistem

Pada tahap ini membahas tentang aliran dokumentasi pada tempat penelitian berdasarkan observasi peneliti, analisa sistem meliputi penjelasan algoritma dan teknik/metode yang digunakan.

3. Perancangan Sistem

Tahap ini merupakan pembuatan gambar proses 
sistem melalui use case diagram, activity diagram, class diagram, dan sequence diagram yang sesuai dengan kebutuhan sistem

4. Implementasi Sistem

5. Pada tahap ini akan dibuat sistem dengan rancangan yang telah dibuat sebelumnya.

6. Uji Coba dan Evaluasi

Sistem diuji dengan pengujian testing dan mengevaluasi kekurangan serta kelemahan sistem.
Tahap analisis kebutuhan sistem (requirement specification) merupakan tahapan pengembangan sebuah sistem informasi. Bentuk flow of document (flowchart dokumen) berdasarkan pengamatan di tempat penelitian, Gambar 1. Untuk menjelaskan Naive Bayes, proses klasifikasi memerlukan sejumlah petunjuk untuk menentukan kelas yang cocok bagi sampel yang dianalisis, Gambar 2.

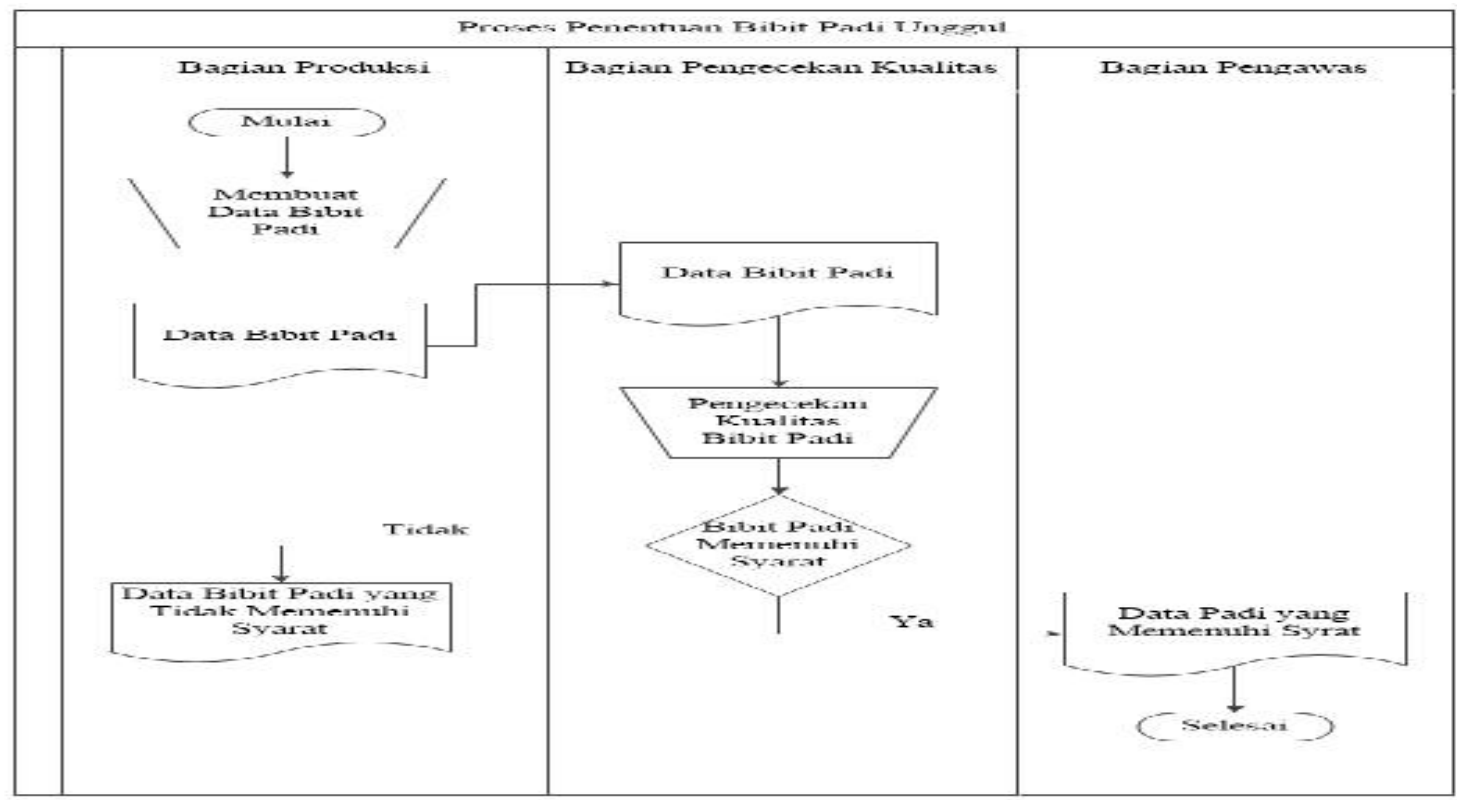

Gambar 1. Flow of Document Penentuan Bibit Padi Unggul

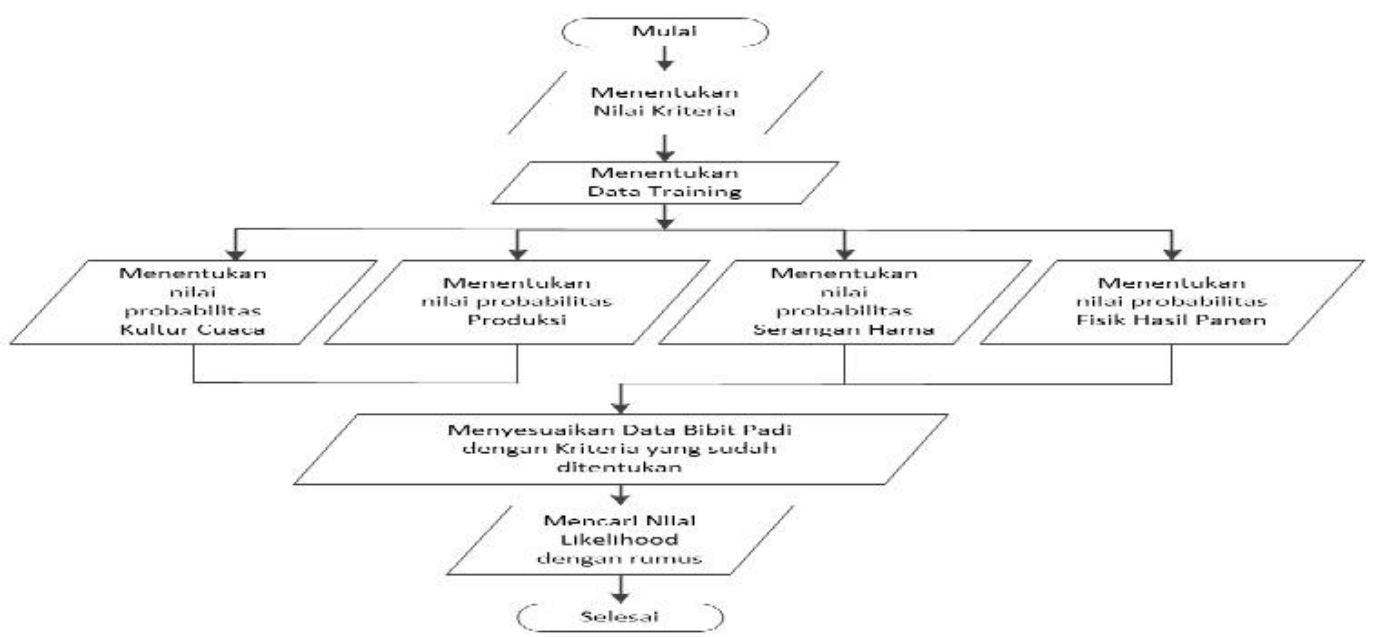

Gambar 2. Flowchart Naive Bayes

4. Hasil dan Pembahasan Kriteria pemilihan bibit padi unggul terbaik didasarkan pada pertimbangan ketahanan-ketahanan terhadap hama dan kualitas beras yang baik serta 
kecepatan pertumbuhan atau rentan terhadap penyakit. Terdapat beberapa jenis bibit padi unggul yang sering dibudidayakan, diantaranya biasa digunakan untuk bercocok tanam para petani adalah Mira, Ciherang, Mikongga, Cibogo dan Inpari 1-46. Model statistik merupakan salah satu model yang terpercaya sangat andal sebagai pendukung pengambilan keputusan. Konsep probabilitas merupakan salah satu bentuk model statistik. Salah satu metode yang menggunakan konsep probabilitas adalah Naive Bayesian Classification (NBC). Semua atribut akan memberikan kontribusinya dalam pengambilan keputusan dengan bobot atribut yang sama penting dan setiap atribut saling bebas satu sama lain. Apabila diberikan $\mathrm{k}$ atribut yang saling bebas (independence). Jika atribut ke-i bersifat diskret, maka $\mathrm{P}(\mathrm{xi} \mid \mathrm{C})$ diestimasi sebagai frekuensi relatif dari sampel yang memiliki nilai xi sebagai atribut ke i dalam kelas C. Namun, jika atribut ke-i bersifat kontinu, maka $\mathrm{P}(\mathrm{xi} \mid \mathrm{C})$ diestimasi dengan fungsi Densitas Gauss. Penyelesaian studi kasus dalam pemilihan jenis bibi padi unggul terbaik di perlukan sebuah data yang akan digunakan didalam penerapan metode Naive Bayes, yaitu variabel dan himpunan.
Tabel 5. Tabel Variabel Dan Himpunan

\begin{tabular}{|c|l|c|}
\hline Kode & \multicolumn{1}{|c|}{ Nama Kriteria } & Himpunan \\
\hline \multirow{2}{*}{ C1 } & Kultur Cuaca & Panas \\
\hline \multirow{2}{*}{ C2 } & \multirow{2}{*}{ Produksi } & Dingin \\
\hline \multirow{2}{*}{ C3 } & Serangan Hama & Rendah \\
\cline { 3 - 3 } & & Renggi \\
\hline C4 & \multirow{2}{*}{ Hasil Panen } & Tinggi \\
\cline { 3 - 3 } & & Rendah \\
\hline
\end{tabular}

Tabel 6. Tabel Kriteria

\begin{tabular}{|c|l|}
\hline Kode & \multicolumn{1}{|c|}{ Nama Padi } \\
\hline R1 & Mira \\
\hline R2 & Ciherang \\
\hline R3 & Mikongga \\
\hline R4 & Cibogo \\
\hline R5 & Inpari 43 GSR \\
\hline R6 & Mapan P-05 \\
\hline R7 & Sertani 13 \\
\hline
\end{tabular}

Data klasifikasi pemilihan jenis bibit padi unggul dengan kualiatas baik berdasarkan kriteria-kriteria yang ada.

1. Klasifikasi pemilihan jenis bibit padi unggul dibudidayakan berdasarkan kriteria-kriteria yang ada.

Tabel 7. Data Training

\begin{tabular}{|c|l|l|l|l|l|}
\hline No & Kultur Cuaca & Produksi & Serangan Hama & Hasil Panen & Jenis Padi \\
\hline 1 & Panas & Rendah & Rendah & Rendah & Mira \\
\hline 2 & Panas & Rendah & Rendah & Tinggi & Ciherang \\
\hline 3 & Panas & Rendah & Rendah & Tinggi & Mikongga \\
\hline 4 & Dingin & Tinggi & Tinggi & Rendah & Ciibogo \\
\hline 5 & Dingin & Tinggi & Tinggi & Tinggi & Inpari 43 GSR \\
\hline 6 & Dingin & Tinggi & Rendah & Tinggi & Mapan P-05 \\
\hline 7 & Dingin & Tinggi & Rendah & Tinggi & Sertani 13 \\
\hline 8 & Panas & Tinggi & Tinggi & Rendah & Mira \\
\hline 9 & Panas & Tinggi & Rendah & Tinggi & Ciherang \\
\hline 10 & Panas & Tinggi & Rendah & Tinggi & Mikongga \\
\hline 11 & Dingin & Rendah & Tinggi & Tinggi & Ciibogo \\
\hline 12 & Dingin & Rendah & Tinggi & Tinggi & Inpari 43 GSR \\
\hline 13 & Dingin & Rendah & Rendah & Tinggi & Mapan P-05 \\
\hline 14 & Dingin & Rendah & Rendah & Tinggi & Sertani 13 \\
\hline 15 & Dingin & Rendah & Tinggi & Tinggi & Mira \\
\hline 16 & Dingin & Rendah & Tinggi & Rendah & Ciherang \\
\hline 17 & Dingin & Rendah & Tinggi & Rendah & Mikongga \\
\hline 18 & Panas & Tinggi & Rendah & Tinggi & Ciibogo \\
\hline 19 & Panas & Rendah & Rendah & Rendah & Inpari 43 GSR \\
\hline 20 & Panas & Tinggi & Tinggi & Rendah & Mapan P-05 \\
\hline 21 & Panas & Tinggi & Tinggi & Rendah & Sertani 13 \\
\hline
\end{tabular}

2. Menentukan probabilitas variabel terhadap kategori, dari data training ditentukan nilai probabilitas dari tiap-tiap variabel: a) Probabilitas kultur cuaca pada setiap kategori bibit padi

Tabel 8. Probabilitas Kultur Cuaca

\begin{tabular}{|c|c|c|c|c|c|c|c|c|c|c|c|c|c|c|}
\hline \multirow{2}{*}{ Himpunan } & \multicolumn{4}{|c|}{ Jumlah Kategori Kultur Cuaca } & \multicolumn{4}{|c|}{ Probabilitas Kategoro Kultur Cuaca } \\
\cline { 2 - 12 } & R1 & R2 & R3 & R4 & R5 & R6 & R7 & R1 & R2 & R3 & R4 & R5 & R6 & R7 \\
\hline
\end{tabular}




\begin{tabular}{|l|c|c|c|c|c|c|c|c|c|c|c|c|c|c|}
\hline Panas & 2 & 2 & 2 & 1 & 1 & 1 & 1 & 0.2 & 0.2 & 0.2 & 0.1 & 0.1 & 0.1 & 0.1 \\
\hline Dingin & 1 & 1 & 1 & 2 & 2 & 2 & 2 & 0.09 & 0.09 & 0.09 & 0.18 & 0.18 & 0.18 & 0.18 \\
\hline
\end{tabular}

b) Probabilitas produksi pada setiap kategori jenis bibit padi

Tabel 9. Probabilitas Produksi

\begin{tabular}{|c|c|c|c|c|c|c|c|c|c|c|c|c|c|c|}
\hline \multirow{2}{*}{ Himpunan } & \multicolumn{7}{|c|}{ Jumlah Kategori Produksi } & \multicolumn{7}{|c|}{ Probabilitas Kategoro Produksi } \\
\hline & R1 & $\mathrm{R} 2$ & R3 & $\mathrm{R} 4$ & R5 & R6 & R7 & $\mathrm{R} 1$ & R2 & R3 & $\mathrm{R} 4$ & R5 & R6 & R7 \\
\hline Ren & 2 & 2 & 2 & 1 & 2 & 1 & 1 & 0.2 & 0.2 & 0.2 & 0.1 & 0.2 & 0.1 & 0.1 \\
\hline Tingggi & 1 & 1 & 1 & 2 & 1 & 2 & 2 & 0.1 & 0.09 & 0.09 & 0.2 & 0.09 & 0.18 & 0.18 \\
\hline
\end{tabular}

c) Probabilitas serangan hama pada setiap kategori jenis bibit padi unggul

Tabel 10. Probabilitas Serangan Hama

\begin{tabular}{|c|c|c|c|c|c|c|c|c|c|c|c|c|c|c|}
\hline \multirow{2}{*}{ Himpunan } & \multicolumn{7}{|c|}{ Jumlah Kategori Serangan Hama } & \multicolumn{7}{|c|}{ Probabilitas Kategori Serangan Hama } \\
\hline & $\mathrm{R} 1$ & $\mathrm{R} 2$ & R3 & $\mathrm{R} 4$ & $\mathrm{R} 5$ & R6 & R7 & $\mathrm{R} 1$ & $\mathrm{R} 2$ & R3 & $\mathrm{R} 4$ & R5 & R6 & R7 \\
\hline Rendah & 1 & 2 & 2 & 1 & 1 & 2 & 2 & 0.09 & 0.18 & 0.18 & 0.09 & 0.09 & 0.18 & 0.18 \\
\hline Tinggi & 2 & 1 & 1 & 2 & 2 & 1 & 1 & 0.2 & 0.1 & 0.1 & 0.2 & 0.2 & 0.09 & 0.1 \\
\hline
\end{tabular}

d) Probabilitas ketahanan penyakit pada setiap

kategori jenis bibit padi

Tabel 11. Probabilitas Hasil Panen

\begin{tabular}{|l|c|c|c|c|c|c|c|c|c|c|c|c|c|c|}
\hline \multirow{2}{*}{ Himpunan } & \multicolumn{4}{|c|}{ Jumlah Kategori Hasil Panen } & \multicolumn{4}{c|}{ Probabilitas Kategori Hasil Panen } \\
\cline { 2 - 25 } & R1 & R2 & R3 & R4 & R5 & R6 & R7 & R1 & R2 & R3 & R4 & R5 & R6 & R7 \\
\hline Rendah & 2 & 1 & 1 & 1 & 1 & 1 & 1 & 0.25 & 0.25 & 0.25 & 0.25 & 0.25 & 0.25 & 0.25 \\
\hline Tinggi & 1 & 2 & 2 & 2 & 2 & 2 & 2 & 0.07 & 0.07 & 0.07 & 0.07 & 0.07 & 0.07 & 0.07 \\
\hline
\end{tabular}

e) Probabilitas untuk setiap kategori jenis bibit padi

Tabel 12. Probabilitas Jenis Bibit Padi

\begin{tabular}{|l|c|c|c|c|c|c|c|}
\hline \multirow{2}{*}{ Himpunan } & \multicolumn{7}{|c|}{ Probabilitas Kriteria Jenis Bibit Padi } \\
\cline { 2 - 8 } & R1 & R2 & R3 & R4 & R5 & R6 & R7 \\
\hline Jumlah & $3 / 21$ & $3 / 21$ & $3 / 21$ & $3 / 21$ & $3 / 21$ & $3 / 21$ & $3 / 21$ \\
\hline
\end{tabular}

Dalam pengguna menginputkan data kriteria jenis Likelihood $\mathrm{R} 4=0.18 * 0.2 * 0.18 * 0.07 * 0.14$ bibit padidengan kriteria a. Kultur Cuaca : Panas b. $=0.0000463 \quad$; Likelihood Produksi : Tinggi c. Serangan Hama : Rendah d. R5=0.18*0.1*0.18*0.07*0.14 = 0.0000231 ; Hasil Panen : Tinggi

f) Mencari Likelihood dan Probabilitas

Likelihood R6 $=0.18 * 0.2 * 0.09 * 0.07 * 0.14=$

1) Perhitungan Likelihood
0.0000463
;
Likelihood

Likelihood R1 $=0.19 * 0.1 * 0.18 * 0.07 * 0.19 \quad=\quad 2)$ Hasil Perhitungan : R1 = $0.0665322581 ; \mathrm{R} 2=$ 0.0000231 ; Likelihood R2=0.09*0.1*0.18*0.7*0.14 $0.3334533669 ; \mathrm{R} 3=0.3334533669 \mathrm{R} 4=$ $=\quad 0.0000926 \quad ; \quad$ Likelihood

$0.1429012346 ; \mathrm{R} 5=0.0665322581 ; \mathrm{R} 6=$ $\mathrm{R} 3=0.09 * 0.1 * 0.9 * 0.7 * 0.14 \quad=0.0000926 ; 0.1429012346 ; \mathrm{R} 7=0.1429012346$

Tabel 13. Perangkingan

\begin{tabular}{|l|l|c|l|}
\hline Kode & \multicolumn{1}{|c|}{ Nama Bibit } & Nilai Probabilitas & \multicolumn{1}{|c|}{ Keterangan } \\
\hline R2 & Ciherang & 0.3334534 & Kualitas Baik \\
\hline R3 & Mikongga & 0.3334534 & Kualitas Baik \\
\hline R4 & Cibogo & 0.1429012 & Kualitas Kurang Baik \\
\hline R6 & Mapan P-05 & 0.1429012 & Kualitas Kurang Baik \\
\hline R7 & Sertani 13 & 0.1429012 & Kualitas Kurang Baik \\
\hline R1 & Mira & 0.0665323 & Kualitas Kurang Baik \\
\hline R5 & Inpari 43 GSR & 0.0665323 & Kualitas Kurang Baik \\
\hline
\end{tabular}

Implementasi sistem merupakan tampilan interface program hasil perancangan, Form menu utama adalah tampilan selanjutnya setelah user atau admin melakukan login, dengan menggunakan Form dibuat Menu Utama Program yang memiliki beberapa bagian menu program yaitu : Menu File, Menu
Proses, Laporan dan Keluaran. Didalam Menu Utama terdapat Menu File yang memiliki 3 bagian sub menu program yaitu : Data Bibit, Data kriteria, dan Data Training dimana dalam masing-masing sub menu program terdapat beberapa sub menu pendukung. Form data kriteria merupakan form yang digunakan admin untuk menambahakan data 
kriteria, mengubah dan menghapus data kriteria, Gambar 3, Form data bibit digunakan untuk menginputkan data bibit, Gambar 4, Form data training digunakan untuk menginputkan data training dalam menentukan kualitas jenis bibit padi, Gambar

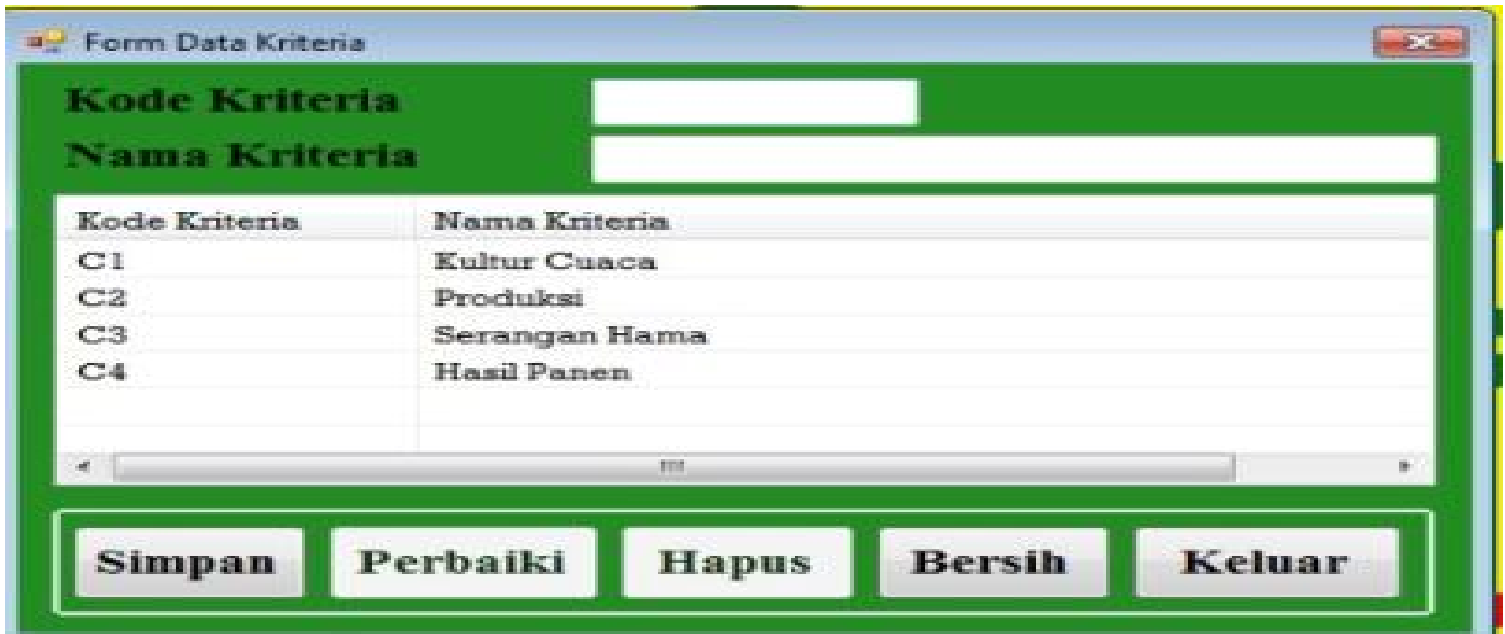

Gambar 3. Form Data Kriteria

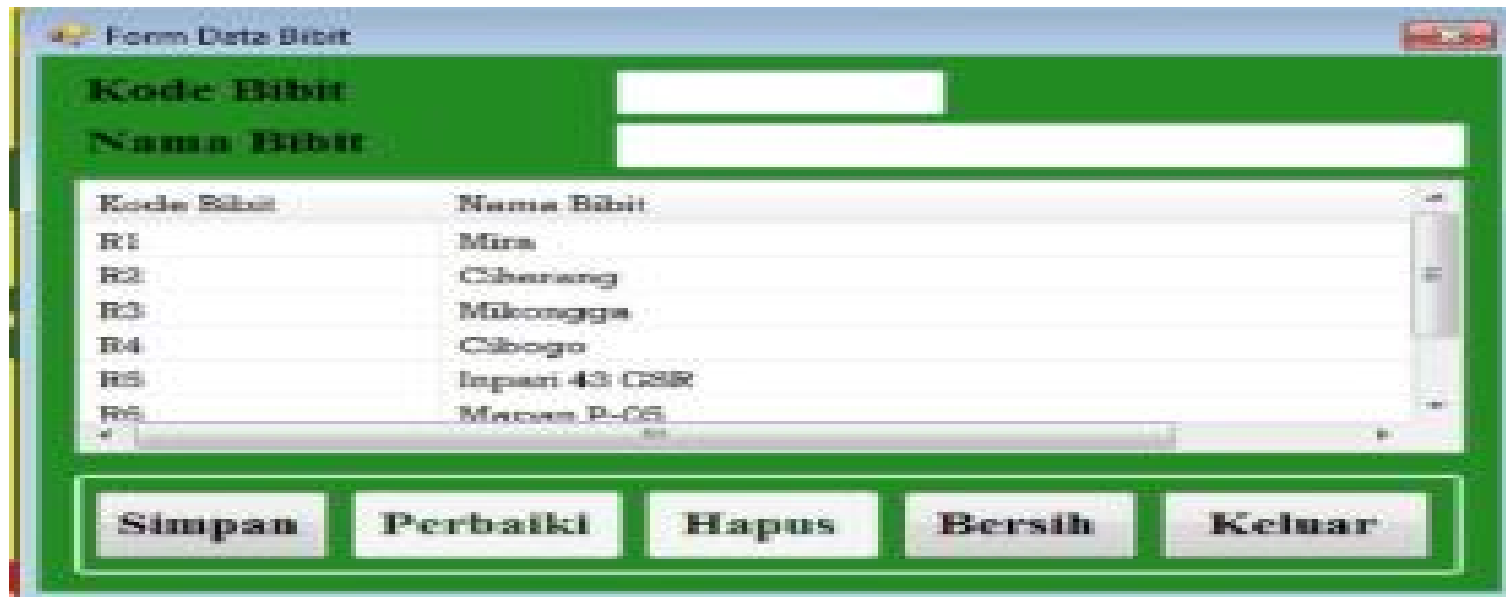

Gambar 4. Form Data Bibit

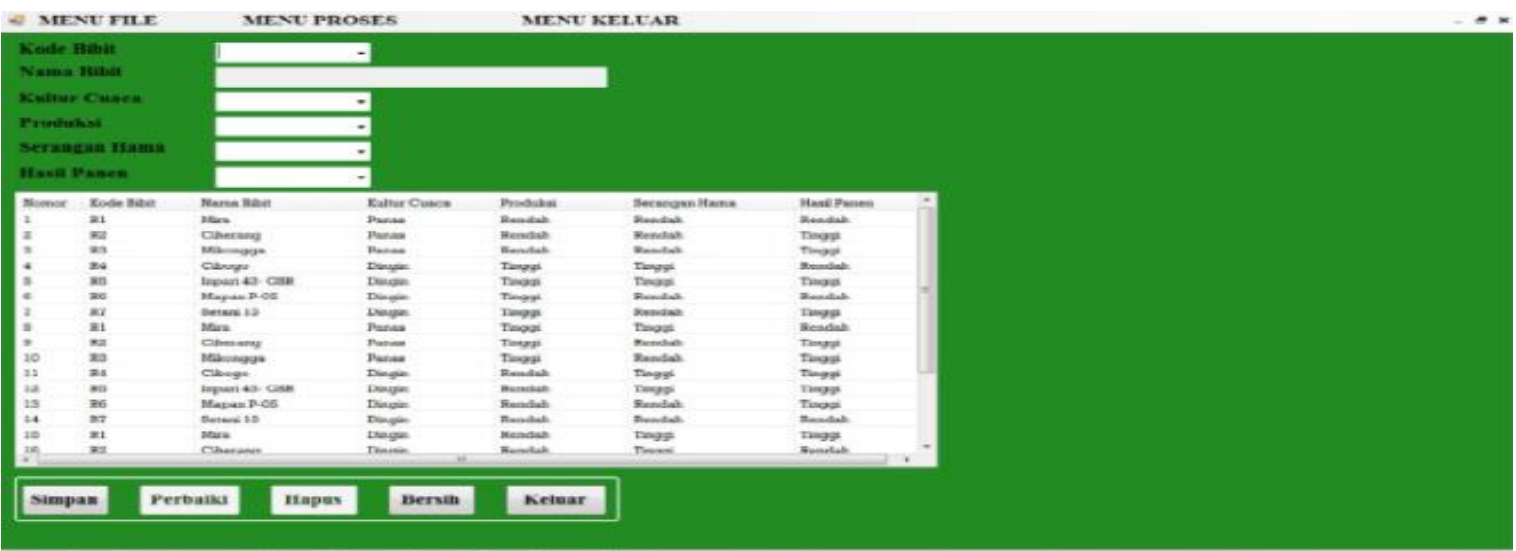

Gambar 5. Form Data Training 
Form analisa data digunakan untuk menghitung penilaian dengan menggunakan metode naive bayes,

\section{Gambar 6.}

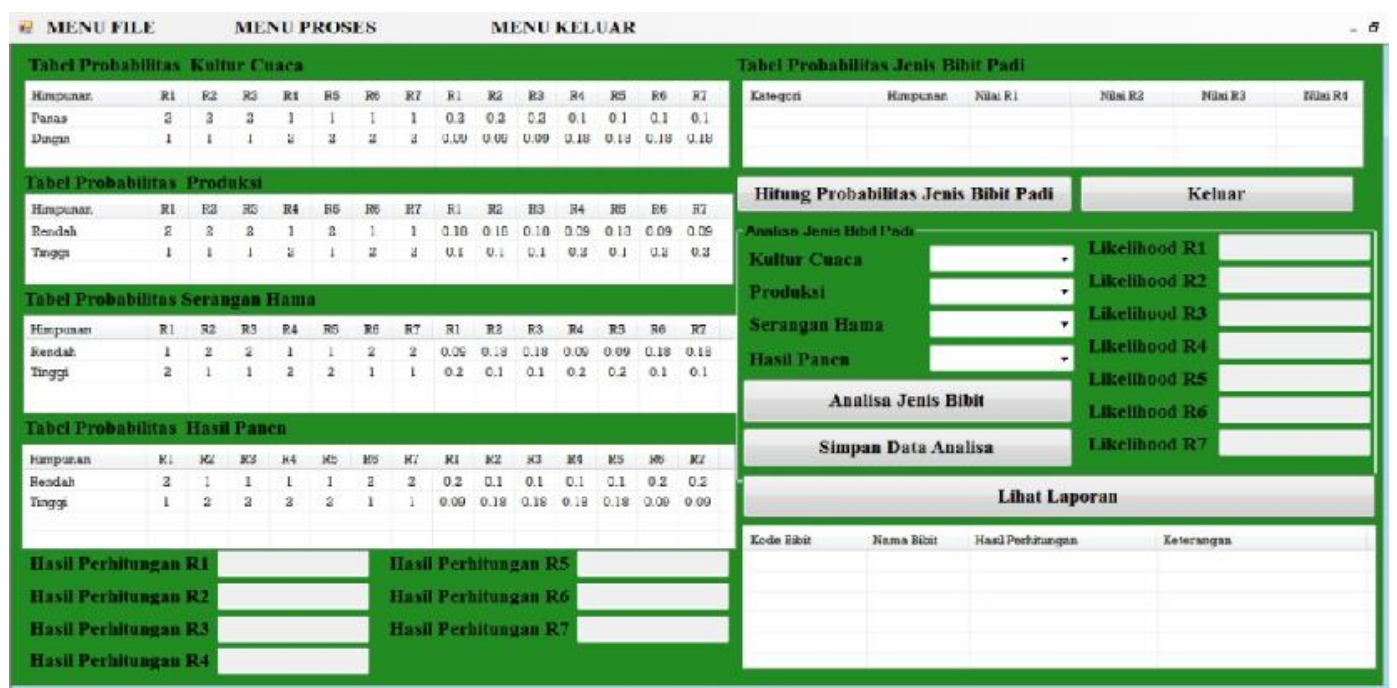

Gambar 6. Form Analisa Data

\section{Kesimpulan}

Setelah melakukan analisa dan pengujian terhadap sistem, kesimpulan penelitian sebagai berikut:

1. Hasil perhitungan probabilitas pada setiap kategori Umur Tanaman: Panas, produksi : Tinggi, Serangan Hama: Rendah, Ketahanan Penyakit: Tinggi. Perhitungan probabilitas mempengaruhi Likelihood

2. Dari lima jenis bibit yang diteliti dengan perhitungan Naive Bayes, urutan perangkingan $\mathrm{R} 2$ - R3 - R4 - R6 - R7 - R1 - R5, diperoleh 2 bibit berkualitas baik yaitu Bibit Kode R2 dan Kode R3 dengan Nilai Probabilitas 0.3334534 dan 0.3334534 .

3. Sistem ini dapat mempertimbangkan konsistensi yang logis dalam penilaian yang digunakan sehingga menghasilkan alternatif yang tidak banyak dibandingkan dengan sistem lama yang tidak memiliki konsistensi yang logis dalam melakukan penilaian.

\section{Daftar Pustaka}

[1] Rudy Agus Santoso, Dahnial Syauqy, Mochammad Hannats Hanafi Ichsan, Pengembangan Sistem Prediksi Hama Wereng Berdasarkan Data Cuaca Sensor Dan Cuaca Online Menggunakan Metode Naive Bayes, Jurnal Pengembangan Teknologi Informasi dan Ilmu Komputer, Vol. 2, No. 10, Oktober 2018, hlm. 4002-4010.

[2] Acihmah Sidauruk, Ade Pujianto, Sistem Pakar Diagnosa Penyakit Tanaman Kelapa Sawit Menggunakan Teorema Bayes, Jurnal Ilmiah
DASI Vo 1. 18 No. 1 Hlm. 51-56 Tahun 2017.

[3] Alfa Saleh, "Implementasi Metode Klasifikasi Naïve Bayes Dalam Memprediksi Besarnya Penggunaan Listrik Rumah Tangga”, Vol. 2, No. 3, Mei hal. 207-217, 2015 - Juli 2015.

[4] Harifuddin, 2007, Estimasi Kebutuhan Daya Listrik Sulawesi Selatan Sampai Tahun 2017, Media Elektrik, No. 2 Vol. 2, Hal 14-22.

[5] Achmad Syarifudin, Nurul Hidayat, Lutfi Fanani, Sistem Pakar Diagnosis Penyakit Pada Tanaman Jagung Menggunakan Metode Naive Bayes Berbasis Android, Jurnal Pengembangan Teknologi Informasi dan Ilmu Komputer, Vol. 2, No. 7, Juli 2018, hlm. 2738-2744.

[6] Andi Riswansyah, Sumiati, Harsiti, Eva Safaah, Diagnosa Hama dan Penyakit Tanaman Padi Menggunakan Metode Bayes, Seminar Nasional Riset Terapan 2017, SENASSET 2017.

[7] Sri Rahayu, Anita Sindar Sinaga, Penerapan Metode Naive Bayes Dalam Pemilihan Kualitas Jenis Rumput Taman CV. Rumput Kita Landscape, Jurnal Teknologi Informasi \& Komunikasi Digital Zone 9 (2), 162-173, 2018.

[8] A Sindar RMS, Sistem Bilangan Digital, Penerbit CV. AA. Rizky Serang Banten, Oktober 2019.

[9] Manjusha K. K., Sankaranarayanan, K., Seena P., 2014, Prediction of Different Dermatological Conditions Using Naive Bayesian Classification, International Journal of Advanced Research in Computer Science and Software Engineering, Vol 4, No 1, Hal 864- 868. 
[10] R Simalango, ASRM Sinaga, Bayes Diagnosa Penyakit Ikan Hias Air Tawar Dengan Teorema Bayes, Journal Publications \& Informatics Engineering Research (SinKron), 3 (1), 43-5, Tahun 2018.

[11] Y Yuliyana, ASRM Sinaga, Sistem Pakar Diagnosa Penyakit Gigi Menggunakan Metode Naive Bayes Fountain of Informatics Journal 4 (1), 19-23, Tahun 2019.

[12] Feri Hari Utami, Penentuan Tingkat Kesuburan Tanah Di Balai Penyuluhan Pertanian Perikanan Dan Kehutanan Dengan Menggunakan Algoritma Naive Bayes Dalam Data Mining, Riau Journal of Computer Science Vol.1, No.1, 27- 38. Tahun 2015. 